\title{
Medulloblastoma associated with novel PTCH mutation as primary manifestation of Gorlin syndrome
}

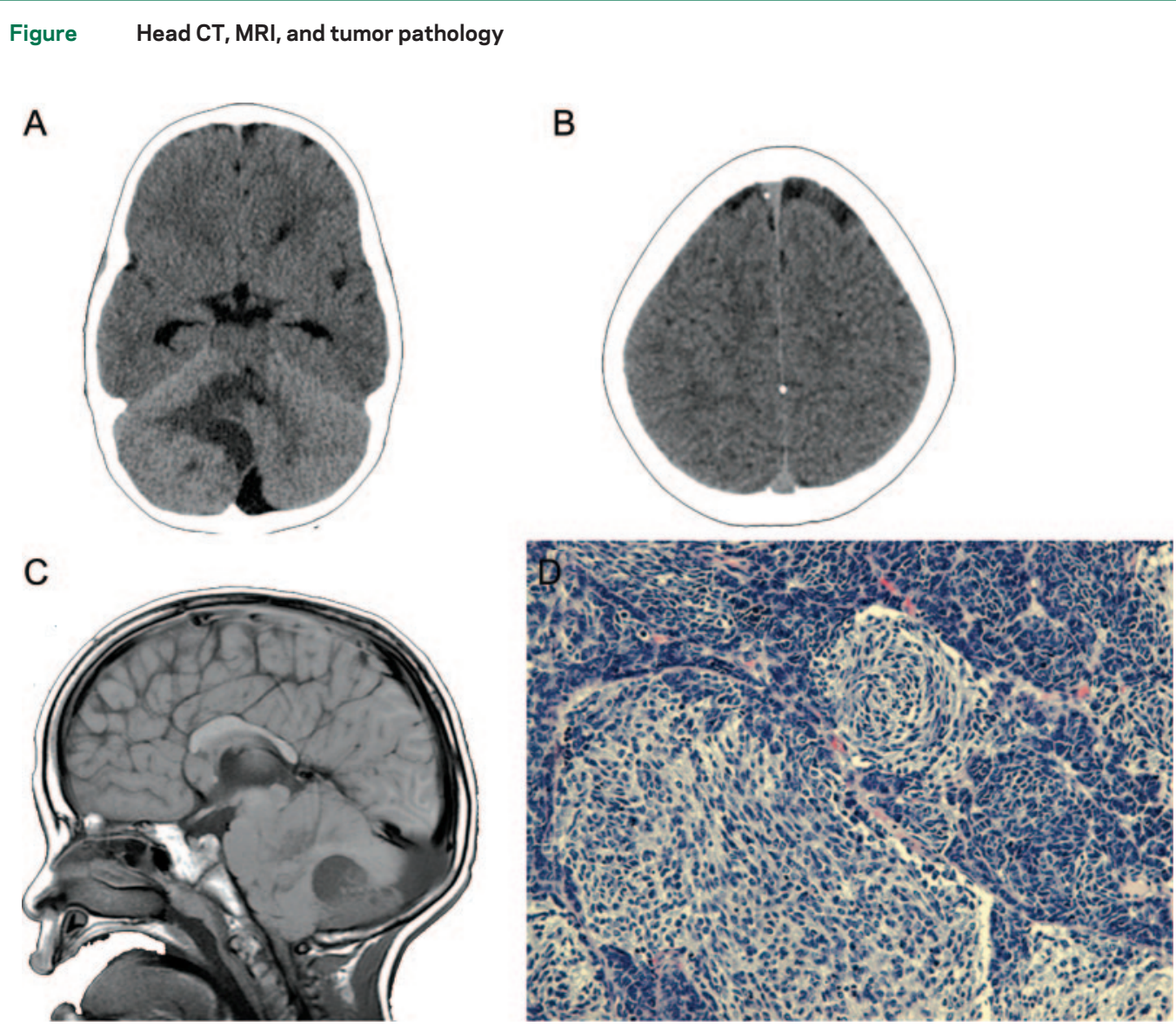

(A) Noncontrast head CT shows a posterior fossa mass with associated hydrocephalus and parafalcine nodular calcifications (B). (C) Sagittal T1 noncontrast MRI further reveals macrocephaly and hypogenetic corpus callosum. (D) Hematoxylin \& eosin-stained tumor specimen demonstrates the reticular-nodular appearance of desmoplastic medulloblastoma.

A 3-year-old boy with a history of developmental delay presented with a 2-week history of vomiting and irritability. Neurologic examination revealed an encephalopathic child without focal deficits. Parafalcine nodular calcifications on head CT (figure, B) in association with hypogenetic corpus callosum on MRI (figure, C) and desmoplastic medulloblastoma pathology (figure, D) raised suspicion for basal cell carcinoma nevus syndrome (Gorlin syndrome). ${ }^{1}$ Falcine calcifications are rare in children and can be associated with trauma, infection, meningiomas, and pseudohypoparathyroidism. PTCH tumor suppressor gene mutation analysis demonstrated a novel Y601X nonsense mutation in exon 13. Based on the genetic findings, radiation therapy was withheld in our patient due to the risks of secondary malignancies in patients with Gorlin syndrome. ${ }^{2}$

John R. Crawford, MD, MS, Brian R. Rood, MD, Christopher T. Rossi, MD, Gilbert Vezina, MD, Washington, DC

Disclosure: The authors report no disclosures.

Address correspondence and reprint requests to Dr. John R. Crawford, Department of Neurology, Children's National Medical Center, The George Washington University, Washington, DC 20010; jcrawfor@cnmc.org

1. Kimonis VE, Mehta SG, Digiovanna JJ, Bale SJ, Pastakia B. Radiological features in 82 patients with nevoid basal cell carcinoma (NBCC or Gorlin) syndrome. Genet Med 2004;6:495-502.

2. Epstein EH. Basal cell carcinomas: attack of the hedgehog. Nat Rev Cancer 2008;10:743-754. 


\section{Neurology}

\section{Medulloblastoma associated with novel $\mathrm{PTCH}$ mutation as primary manifestation of Gorlin syndrome}

John R. Crawford, Brian R. Rood, Christopher T. Rossi, et al.

Neurology 2009;72;1618

DOI 10.1212/WNL.0b013e3181a413d6

\section{This information is current as of May 4, 2009}

\section{Updated Information \&} Services

References

\section{Subspecialty Collections}

Permissions \& Licensing

Reprints including high resolution figures, can be found at: http://n.neurology.org/content/72/18/1618.full

This article cites 2 articles, 0 of which you can access for free at: http://n.neurology.org/content/72/18/1618.full\#ref-list-1

This article, along with others on similar topics, appears in the following collection(s):

Primary brain tumor

http://n.neurology.org/cgi/collection/primary_brain_tumor

Information about reproducing this article in parts (figures,tables) or in its entirety can be found online at:

http://www.neurology.org/about/about_the_journal\#permissions

Information about ordering reprints can be found online:

http://n.neurology.org/subscribers/advertise

Neurology ${ }^{\circledR}$ is the official journal of the American Academy of Neurology. Published continuously since 1951, it is now a weekly with 48 issues per year. Copyright . All rights reserved. Print ISSN: 0028-3878. Online ISSN: 1526-632X.

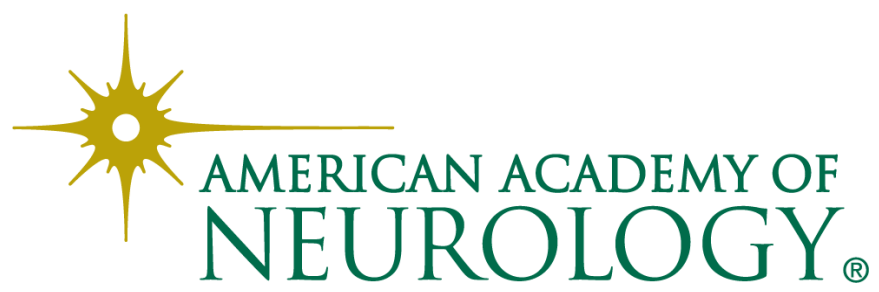

